\title{
Screening of resistant germplasm against powdery mildew of pea and its management through nutrients and plant activators
}

\author{
Amna Ikram1, Hafiz Muhammad Usman Aslam²*, Muhammad Atiq ${ }^{2}$, Luqman Amrao², Safdar Ali2, \\ Nasir Ahmad Khan ${ }^{2}$, Khalid Naveed ${ }^{3}$ \\ ${ }^{1}$ Department of Pest warning and Quality control of Pesticides, Punjab, Pakistan \\ ${ }^{2}$ Department of Plant Pathology, University of Agriculture, Faisalabad, Pakistan \\ ${ }^{3}$ Department of Plant Pathology, University of Agriculture, Sub-campus Depalpur, Okara, Pakistan
}

\begin{abstract}
Received:
October 08,2019

Accepted:

November 17, 2019

Published:

February 17, 2020

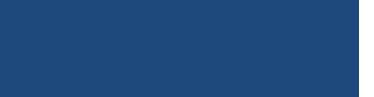

Abstract

In Pakistan, powdery mildew of pea is an emerging pathogen to notable production of pea. The research was conducted to evaluate the currently available resistant source against the powdery mildew (Erysiphe pisi) and its management through nutrients (micronutrients and macronutrients) and plant activators (citric acid, benzoic acid, salicylic acid, K2HPO4, KH2PO4). Thirteen varieties/lines were grown under a randomized complete block design (RCBD). The data of disease incidence were examined at weekly intervals to evaluate the resistant source against this disease. Varieties/lines including No. 267, F-16, and Peas-2009 exhibited a resistant response to $E$. pisi with a disease incidence of $3.3,6.6$, and $1.6 \%$ respectively. The winner showed moderately resistant response with disease incidence $23.46 \%$. Green grass (45.05\%), VIP (37.7\%), Peas meto (29.50\%), Aleena (30.63\%) and Azad (36.00\%) were moderately susceptible. The Varieties PF-450 (65.00\%), and Sprinter (61.70\%) showed susceptible response. The Varieties Climax (74.00\%) and Meteor (73.53\%) were highly susceptible to powdery mildew. The macronutrients proved to be the highly effective with lowest disease incidence as $8.14 \%$. Salicylic acid was the most effective plant activator followed by K2HPO4 that exhibited the minimum diseases incidence $16.38 \%$ and $22.62 \%$ respectively. Our findings concluded that the variety Peas-2009 was highly resistant against the powdery mildew. Macronutrients and salicylic acid (SA) were highly potent nutrient and plant activator in minimizing the development of this radical fungal pathogen.
\end{abstract}

Keywords: Screening, Pisum sativum, Nutrients, Erysiphe pisi, Plant activators

\section{How to cite this:}

Ikram A, Aslam HMU, Atiq M, Amrao L, Ali S, Khan NA and Naveed K, 2020. Screening of resistant germplasm against powdery mildew of pea and its management 


\section{Introduction}

Pea (Pisum sativum L.) is an important member of the Fabaceae family and a highly significant legume plant, ranked third after soya bean and common beans (Azmat et al., 2010). In Pakistan the annual production of this crop was 105 thousand metric tons under the total cultivable area was 15,800 hectares (Naeem et al., 2018). Pea is considered as the highly nutritious portion of the human food as it comprises $42.65 \%$ carbohydrates, $27.8 \%$ proteins and vital minerals like iron $(\mathrm{Fe})$, sodium $(\mathrm{Na})$, phosphorus $(\mathrm{P})$, potassium $(\mathrm{K})$ and some other important elements. The seeds of pea have some medicinal properties as it is used in curing of many fungal diseases (Muneer et al., 2018).

Different components, including insect pests, diseases, temperature, humidity and rainfall affects the successful production of pea (Katoch et al., 2010). A number of factors affecting the pea production in Pakistan and globally, but the fungal pathogen (Erysiphe pisi) responsible for powdery mildew are considered to be the major limiting threat. Under promising situations, this disease affects both the quality and quantity of the pea crop and responsible for up to $80 \%$ yield loss (Sun et al., 2016). However, the powdery mildew is more rampant in late maturing or late sown pea varieties. The disease is generally occurred in January to the last week of February when plants are producing pods (Ali et al., 2007). Powdery mildew first appears in the upper central part of the young leaves as slight, round and spotted white colonies (4-5 $\mathrm{mm}$ diameter) which eventually coalesce. The colonies ultimately covered the whole leaf under suitable environmental conditions. As the disease progress the colony color was altered from white to grayish brown. Later on, the entire leaf surface is covered with the fungal sporulation and the pathogen steadily moves towards the lower leaf surface. The lower surface of severely infected leaves exhibit fine white powder which also occurs on midribs, veins and veinlets (Fondevilla and Rubiales, 2012).

Several methods were employed to counter the effect of powdery mildew i.e. the usage of chemicals, but availability of resistant germplasm is the most effective method to combat this disease (Cao et al., 2011). Induced resistance (IR) emerging through normal defense system of the plants is an alternative, non-conventional and environment friendly approach. Its usage into the agricultural system might reduce the level of chemical control, so helping in expansion of sustainable agriculture (Edreva, 2004). Locally, it is expressed at the infection site while systematically at the sites which are distantly situated from the site of primary attack. This type of resistance behavior of plants stimulates the capability to protect the plants against themselves by several pathogens that triggering the species-specific defense mechanisms (Dong and Beer, 2000). The plant activators like salicylic acid (SA), benzoic acid (BA), citric acid (CA), jasmonic acid (JA), $\mathrm{KH}_{2} \mathrm{SO}_{4}$, phosphate salts, riboflavin, potassium and kerosene oils are used to establish systemic acquired resistance (SAR) through signaling trails (Conrath, 2006). The SA is a main signal element in plant protection to counter many fungal, viral and bacterial pathogens (Sreeja, 2014). Usage of salicylic acid on plants not only produces endogenous salicylic acid but also trigger the SAR genes that contribute a substantial role in inducing the resistance against numerous pathogens (Vallad and Goodman, 2004).

Integrated application of plant nutrients helps to control the disease tolerance or resistance of plants. The contemporary effect of nutrients like nitrogen, phosphorus, potassium, manganese, zinc, chlorine, boron and silicon on resistance against different fungal and bacterial diseases and usage of these macro and micro-nutrients in sustainable agriculture has been tested (Dordas, 2009). The use of manures and fertilizers in soil at the proper time enhances the degree of immunity in the crop plants and helps to defeat a disease epidemic. The application of nutrients improves the resistance level of plants against diseases in an inducible manner. The application of nutrients as fertilization, or change in soil properties for nutrient accessibility, is an imperative control method that keeps off the plant from ailments and improves crop yield (Fageria, 2016).

The current study was undertaken to assess the sources of resistance to counter the powdery mildew of pea due to its eco-friendly suitability, cost effectivity and long durability. Besides, there is a need to evaluate the impact of nutrients and plant activators in a sustainable way to overcome the effect of this fundamental pathogen.

\section{Material and Methods}

\section{Raising the pea screening nursery}

Seeds of seven pea varieties/lines (VIP, Green grass, Peas 2009, F-16, PF-450, Sprinter, No. 267) were carried from Ayub Agricultural Research Institute 
(AARI) Faisalabad, Pakistan and six lines/varieties (Meteor, Peas meto, Aleena, Azad, Samrina zard and Climax) were obtained from a local market in Okara, Pakistan. The nursery was grown in the experimental zone of Plant Pathology (PP), University of Agriculture, Faisalabad (UAF) during 2017 and 2018 to evaluate the resistant source against the powdery mildew. Seedlings of pea plants were grown on beds at a distance of $75 \mathrm{~cm}$ apart. The beds were spaced 1.5 $\mathrm{m}$ from each other under the Randomized Complete Block Design (RCBD). All the agronomic practices, together with the application of fertilizers and irrigation schedules were followed to keep the plants healthy. Field plants were exposed to instinctive epidemics of the disease during the flourishing season. The susceptible cultivar "Climax" was cultivated on the border lines around the pea field as check.

\section{Data recording}

The data of disease incidence was recorded at four weeks of interval after the initiation of disease by using the following formula which is further analyzed by the scale (Table: 1) given by Mayee and Datar (1986).

$$
\text { Disease Incidence }(\%)=\frac{\text { No. of diseased plants }}{\text { Total no. of plants }} \times 100
$$

Table-1: Disease assessment scale for the estimation of powdery mildew

\begin{tabular}{|c|c|}
\hline $\begin{array}{l}\text { Disease } \\
\text { Rating }\end{array}$ & Description \\
\hline 0 & leaves free from infection (Immune) \\
\hline 1 & $\begin{array}{l}\text { Small powdery mildew spots covering less } \\
\text { than } 1 \% \text { leaf area (Highly Resistant) }\end{array}$ \\
\hline 3 & Covering $1-10 \%$ of the leaf area (Resistant) \\
\hline 5 & $\begin{array}{l}\text { Powdery mildew lesion enlarging, covering } \\
11-25 \% \text { of the leaf area (Moderately } \\
\text { Resistant) }\end{array}$ \\
\hline 7 & $\begin{array}{l}\text { Lesions coalesce forming large patches } \\
\text { covering } 26-50 \% \text { of the leaf area (Moderately } \\
\text { susceptible) }\end{array}$ \\
\hline 9 & $\begin{array}{l}\text { Powdery mildew patches covering } 51-70 \% \text { of } \\
\text { the leaf area (Susceptible), }\end{array}$ \\
\hline 11 & $\begin{array}{l}\text { Powdery Mildew patches covering more than } \\
70 \% \text { of the leaf area (Highly Susceptible) }\end{array}$ \\
\hline
\end{tabular}

\section{Evaluation of nutrients}

Pea plants (climax) were grown in earthen pots $(3 \mathrm{~kg}$ soil) that were kept under the greenhouse of Plant Pathology, UAF. Before the onset of natural infection, the plants were treated with macronutrients $(\mathrm{P}, \mathrm{N}$ and $\mathrm{K})$ and micronutrients $(\mathrm{Zn}, \mathrm{Cu}, \mathrm{Mg}, \mathrm{Fe}, \mathrm{K}$ and $\mathrm{B})$ in three different concentrations $(0.5 \%, 0.75 \%$, and $1 \%)$. The pea plants sprayed with distilled water served as the control. The treatments were applied under the CRD design with 3 replications. The data of disease incidence was noted after a week interval.

$\mathrm{T}_{1}=$ Macronutrients $(0.5,0.75$ and $1 \%)$

$\mathrm{T}_{2}=$ Micronutrients $(0.5,0.75$ and $1 \%)$

$\mathrm{T}_{3}=$ Control

\section{Evaluation of plant activators}

Citric acid, K2HPO4, benzoic acid, salicylic acid and $\mathrm{KH} 2 \mathrm{PO} 4$ at different concentrations was assessed under the field experiments. The highly susceptible cultivar (climax) was sown in RCBD at the research area of PP, UAF. Citric acid, salicylic acid, K2HPO4, benzoic acid and $\mathrm{KH} 2 \mathrm{PO} 4$ were spray inoculated at 3 different concentrations $(0.5 \%, 1 \%$ and $1.5 \%)$ on pea plants under filed conditions. The check plants were sprayed with sterile distilled water. The data of disease incidence was estimated one week earlier the treatments were applied to the consecutive 3-4 weeks after the application of treatments.

$\mathrm{T}_{1}=$ Citric acid $(0.5,1$ and $1.5 \%)$

$\mathrm{T}_{2}=$ Benzoic acid $(0.5,1$ and $1.5 \%)$

$\mathrm{T}_{3}=\mathrm{KH} 2 \mathrm{PO} 4(0.5,1$ and $1.5 \%)$

$\mathrm{T}_{4}=\mathrm{K} 2 \mathrm{HPO} 4(0.5,1,1.5 \%)$

$\mathrm{T}_{5}=$ Salicylic acid $(0.5,1,1.5 \%)$

$\mathrm{T}_{6}=$ Control

\section{Statistical analysis}

The statistical data was examined with the statistical software (SAS 9.3). The information were exposed to analysis of variance (ANOVA) at five percent significance level. Further, for the statistical comparison among treatments, the least significance difference (LSD) test was used (Steel et al., 1986).

\section{Results}

\section{Screening of resistant germplasm}

A substantial variation was noticed among the pea varieties/lines in terms of disease incidence. The average incidence of powdery mildew was ranged from $1.6 \%$ to $74 \%$. Three pea varieties/lines i.e. No. 267, F-16, and Peas 2009 showed the resistant response with disease score of 3 while the 1 variety 'Winner' exhibited the moderately resistant reaction towards the powdery mildew with rating 5. Likewise, the five lines/varieties i.e. Green grass (45.05\%), VIP (37.7\%), Peas meto (29.50\%), Aleena (30.63\%) and Azad (36.00\%) displayed the moderately susceptible 
action with grade 7. PF-450 (65.00\%), Sprinter $(61.70 \%)$ expressed the susceptible reaction (rating 9) while Climax $(74.00 \%)$, Meteor $(73.53 \%)$ exhibited the maximum disease development (HS) with rating 11 towards the powdery mildew during 2017-2018 (Table 1; Fig. 1).

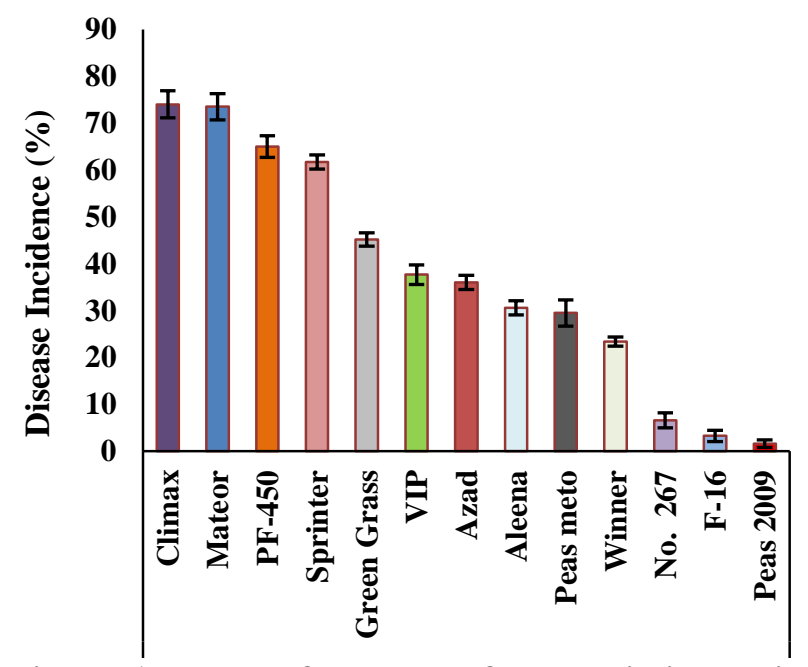

Figure-1: The performance of pea varieties against the fungus $E$. pisi during 2017-2018

\section{Evaluation of nutrients against the powdery mildew}

The results indicated that all the concentrations of macro and micronutrients has expressively inhibited the progress of powdery mildew on pea plants.

Table-2: Effects of treatments, concentrations and treatments $x$ concentrations for the management of powdery mildew

\begin{tabular}{|c|c|c|c|c|c|}
\hline $\begin{array}{l}\text { Treatments } \\
\text { (T) }\end{array}$ & Nutrients & \multicolumn{3}{|c|}{ Disease incidence $(\%)$} & $\begin{array}{l}\operatorname{LSD}(p \\
\leq 0.05)\end{array}$ \\
\hline $\mathrm{T}_{1}$ & Macronutrient & \multicolumn{3}{|c|}{$8.14 \mathrm{c}$} & \multirow{3}{*}{0.32} \\
\hline $\mathrm{T}_{2}$ & Micronutrient & \multicolumn{3}{|c|}{$11.68 \mathrm{~b}$} & \\
\hline $\mathrm{T}_{3}$ & Control & \multicolumn{3}{|c|}{$58.21 \mathrm{a}$} & \\
\hline \multirow[t]{2}{*}{ Treatments } & \multirow[t]{2}{*}{ Nutrients } & \multicolumn{3}{|c|}{$\begin{array}{c}\text { Mean value of } \\
\text { concentrations }(\mathrm{C})\end{array}$} & $\begin{array}{l}\text { LSD } \\
(p \leq\end{array}$ \\
\hline & & $0.5 \%$ & $0.75 \%$ & $1.0 \%$ & 0.05) \\
\hline $\mathrm{T}_{1}$ & Macronutrients & $10.48 \mathrm{~d}$ & $8.51 \mathrm{e}$ & $5.41 \mathrm{~g}$ & \multirow{3}{*}{0.79} \\
\hline $\mathrm{T}_{2}$ & Micronutrients & $16.37 \mathrm{~b}$ & $11.21 \mathrm{c}$ & $7.45 \mathrm{f}$ & \\
\hline $\mathrm{T}_{3}$ & Control & $58.19 \mathrm{a}$ & $58.20 \mathrm{a}$ & $58.24 \mathrm{a}$ & \\
\hline $\begin{array}{c}\mathrm{T} \times \mathrm{C}(p \leq \\
0.05)\end{array}$ & \\
\hline
\end{tabular}

Highly significant $* *$

All the treatments at different concentrations showed an outstanding impact in minimizing the development of powdery mildew under the greenhouse. Among the treatments, macronutrients presented to be the most effective with lowest disease incidence as $8.14 \%$. While the $1 \%$ concentration has verified to be the extremely productive in minimizing the development of pathogen (Table. 2). Similarly, the interaction effect $(\mathrm{T} \times \mathrm{C})$ showed that the macronutrients at $1 \%$ concentration exhibited minimum diseases incidence $(5.41 \%)$ as compared to all the other treatment effects (Fig. 2).

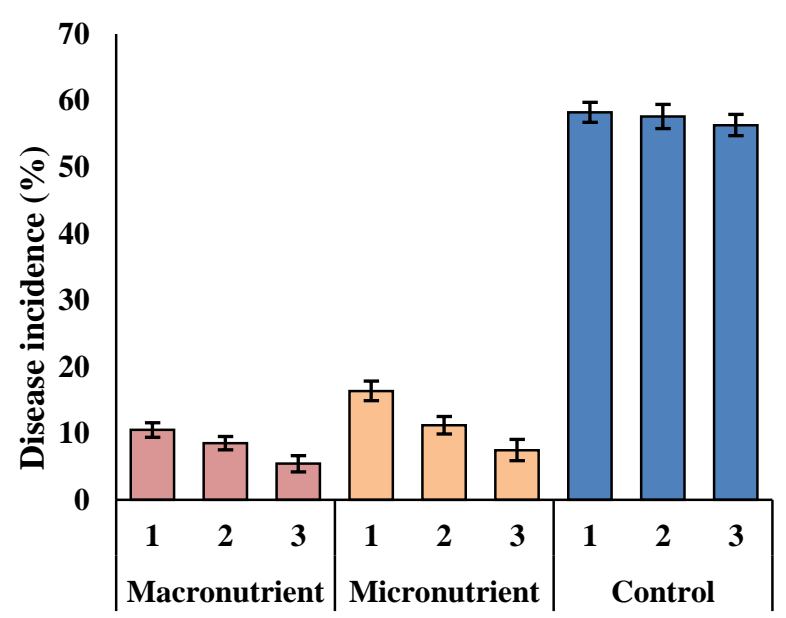

Figure-2: The combine effect of treatments $(T)$ and concentrations $(C)$ for the management of $E$. pisi. The numbers 1-3 represents to the concentrations used in this experiment $(0.5 \%, 0.75 \%$ and $1 \%)$. The least significance value for the interaction effect was 0.79 . The bars above each column were represents to the standard errors.

\section{Assessment of plant activators against the powdery mildew}

The results of plant activators showed that all the treatments at different concentration were significantly inhibited the progress of fungus under the field experiments (Table 3).

Salicylic acid was the most effective plant activator followed by K2HPO4 that exhibited the minimum disease incidence $16.38 \%$ and $22.62 \%$ respectively. The greatest reduction $(11.20 \%)$ in powdery mildew development was observed after the treatment with salicylic acid at $1.5 \%$ concentration. The comparative effect of both the plant activators and concentrations showed the significant interaction against the powdery mildew and concluded that the salicylic acid has the maximum potential in minimizing the development of this disease at higher dose (Fig. 3). 
Table-3: Effect of different treatments (Citric acid, $\mathrm{K}_{2} \mathrm{HPO}_{4}$, salicylic acid, benzoic acid and $\left.\mathrm{KH}_{2} \mathrm{PO}_{4}\right)$ and concentrations $(0.5,0.75$ and $1.5 \%)$ for the management of $E$. pisi

\begin{tabular}{|c|c|c|c|c|c|}
\hline $\begin{array}{l}\text { Treatments } \\
\text { (T) }\end{array}$ & $\begin{array}{c}\text { Plant } \\
\text { Activators }\end{array}$ & \multicolumn{3}{|c|}{ Disease Incidence (\%) } & $\begin{array}{l}\operatorname{LSD}(p \\
\leq 0.05)\end{array}$ \\
\hline $\mathrm{T} 1$ & Salicylic acid & \multicolumn{3}{|c|}{$16.38 \mathrm{f}$} & \multirow{5}{*}{0.15} \\
\hline $\mathrm{T} 2$ & $\mathrm{~K}_{2} \mathrm{HPO}_{4}$ & \multicolumn{3}{|c|}{$22.62 \mathrm{e}$} & \\
\hline $\mathrm{T} 3$ & Citric acid & \multicolumn{3}{|c|}{$27.59 \mathrm{~d}$} & \\
\hline $\mathrm{T} 4$ & $\mathrm{KH}_{2} \mathrm{PO}_{4}$ & \multicolumn{3}{|c|}{$29.80 \mathrm{c}$} & \\
\hline T5 & Benzoic acid & \multicolumn{3}{|c|}{$33.62 \mathrm{~b}$} & \\
\hline T6 & Control & \multicolumn{3}{|c|}{$75.24 \mathrm{a}$} & \\
\hline \multirow{2}{*}{ Treatments } & \multirow{2}{*}{$\begin{array}{c}\text { Plant } \\
\text { Activators }\end{array}$} & \multicolumn{3}{|c|}{$\begin{array}{c}\text { Mean value of } \\
\text { concentration }(C)\end{array}$} & \multirow{2}{*}{$\begin{array}{l}\text { LSD }(p \\
\leq 0.05)\end{array}$} \\
\hline & & $0.5 \%$ & $1.0 \%$ & $1.5 \%$ & \\
\hline $\mathrm{T}_{1}$ & Citric acid & $33.20 \mathrm{e}$ & $27.27 \mathrm{~g}$ & $25.30 \mathrm{~h}$ & \multirow{5}{*}{0.26} \\
\hline $\mathrm{T}_{2}$ & Benzoic acid & $38.27 \mathrm{~b}$ & $33.40 \mathrm{~d}$ & $29.20 \mathrm{f}$ & \\
\hline $\mathrm{T}_{3}$ & $\mathrm{KH}_{2} \mathrm{PO}_{4}$ & $37.03 \mathrm{c}$ & \begin{tabular}{|l|}
$27.17 \mathrm{~g}$ \\
\end{tabular} & $25.20 \mathrm{~h}$ & \\
\hline $\mathrm{T}_{4}$ & $\mathrm{~K}_{2} \mathrm{HPO}_{4}$ & $25.43 \mathrm{~h}$ & $22.40 \mathrm{i}$ & $20.03 \mathrm{j}$ & \\
\hline $\mathrm{T}_{5}$ & Salicylic acid & $20.20 \mathrm{j}$ & $17.73 \mathrm{k}$ & 11.201 & \\
\hline $\mathrm{T}_{6}$ & Control & $75.17 \mathrm{a}$ & $75.30 \mathrm{a}$ & $75.27 \mathrm{a}$ & \\
\hline \multicolumn{2}{|c|}{$\mathrm{T} \times \mathrm{C}(p \leq 0.05)$} & \multicolumn{4}{|c|}{ 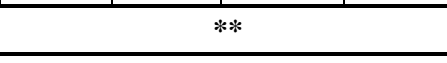 } \\
\hline
\end{tabular}

Highly significant $* *$

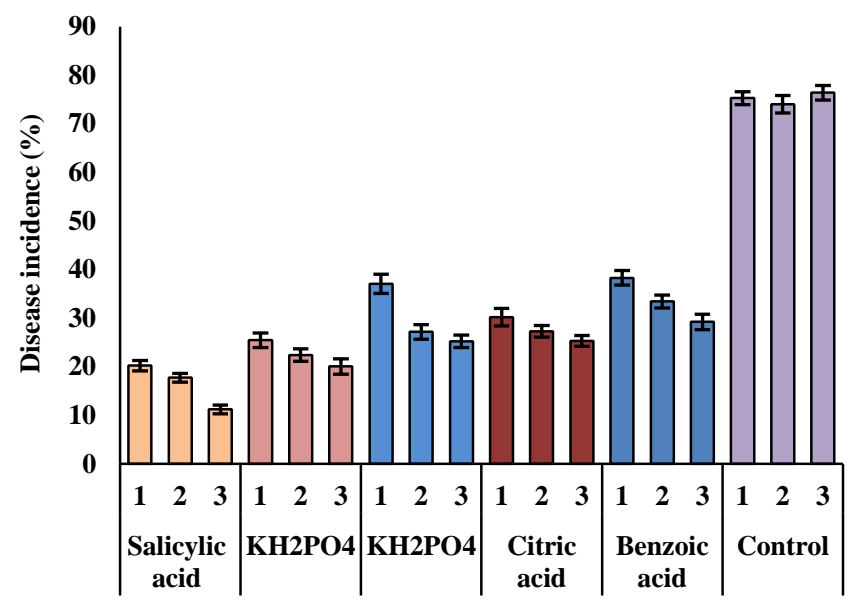

Fig-3: Evaluation of plant activators (Citric acid, benzoic acid, salicylic acid, $\mathrm{K}_{2} \mathrm{HPO}_{4}$ and $\mathrm{KH}_{2} \mathrm{PO}_{4}$ ) at different concentrations $(1=0.5 \%, 2=0.75 \%$ and $3=1.5 \%$ ) for the management of $E$. pisi.

The least significance value for the interaction effect was 0.26 . The bars above each column were represents to the standard errors.

\section{Discussion}

Pisum sativum also known as garden pea is an herbaceous annual plant grown virtually worldwide for its edible seeds. The fungus Erysiphe pisi is the major limiting threat to pea production globally and in favorable conditions responsible for the maximum yield reduction (Hussain et al., 2002). To minimize the infection caused by the powdery mildew, the resistant varieties were the effective process that attained through transferring the resistant genes into susceptible and high yielding cultivars. Although, this process is time consuming, but for the long-term solution, screening of resistant source to counter the powdery mildew is mandatory. The current average per acre yield is very less in Pakistan to support the demands of increasing population. Many efforts were made globally to develop the resistant source of pea against the powdery mildew fungus $E$. pisi. Therefore, this research was focused to analyze the response of pea germplasms against this serious pathogen. Out of thirteen varieties of pea, 2 were highly susceptible, 2 susceptible, 5 moderately susceptible, 1 moderately resistant, 3 varieties exhibited resistant response towards the powdery mildew. Resistance in pea against powdery mildew is inherited by the recessive trait. Two erl and er2 genes were responsible for resistance against powdery mildew in pea plants was identified (Marx, 1971; Fondevilla et al., 2006). Nisar et al. (2006) evaluated the 14 verities/lines against the E. pisi at National Agricultural Research Centre (NARC) in Islamabad, Pakistan. Based on their findings, 3 genotypes were observed to be highly resistant and 11 were moderately susceptible against the disease. These results were confirmed by comparing the field experiments conducted in Agriculture Research Institute Tarnab, Peshawar in which 3 genotypes and 8 pea lines were tested; however, 4 test entries were resistant, 1 moderately susceptible and 3 were susceptible against the Erysiphe pisi (Shahid et al., 2010).

Nutrients are the substances required in large amounts to all living organisms for the completion of their life. Plants also necessitate the simple nutrients like N, K, $\mathrm{P}, \mathrm{Mg}, \mathrm{S}, \mathrm{Ca}$ and $\mathrm{Na}$ (macronutrients), $\mathrm{Cu}, \mathrm{Fe}, \mathrm{Mn}, \mathrm{Cl}$, $\mathrm{Zn}, \mathrm{B}$ and Mo (micronutrients) for various metabolic processes. The mineral nutrition is an imperative facet of plant development that directs the maximum production in all plants. Here in the present research an effort has been made to identify the consequence of Erysiphe pisi on mineral nutrition of pea. The present findings showed that the macronutrients showed to be the highly productive with lowest disease incidence $(8.14 \%)$. It has been noticed that the potassium is one of the main nutrient component for the plant progress 
and several other evolving processes i.e. translocation of proteins, photosynthesis and protein synthesis, and stability of ribosomes, nitrogen uptake, carbohydrates, phosphorylation and glycolysis in plants. In most instances, $\mathrm{K}^{+}$lacking plants found to be highly vulnerable to infection than plants getting the appropriate amount of $\mathrm{K}^{+}$. For example, the fungus $E$. graminis enhanced the potassium uptake in plants (Horsfall, 2012). It is proved by the fact that the infection of barley with rust or powdery mildew fungi has been revealed to amplify the phosphorus concentration in the leaves, either through increased root uptake and subsequent transport to shoot or lessen re-translocation out of the diseased leaves (Veneklaas et al., 2012). The nutrient application to the plants showed a positive interaction i.e. induced the systemic acquired resistance (SAR) and may lessen the disease development (Katoch et al., 2010).

Plants possess a variety of defense mechanisms that can be positively expressed in response to plant pathogens. Systemic acquired resistance (SAR) is a kind of induced resistance in which the plant defense mechanism is preconditioned by prior or mild infection that results in tolerance or resistance against the additional challenges by a pathogen. A number of biological and chemical elicitors have been identified, some of which are commercially accessible for usage in conventional agriculture (Vallad and Goodman, 2004). In our findings, salicylic acid (SA) was discovered to be the highly resourceful plant activator followed by $\mathrm{K}_{2} \mathrm{HPO}_{4}$ that exhibited the minimum diseases incidence $16.38 \%$ and $22.62 \%$ respectively. $\mathrm{SA}$ and BA were found useful in persuading the tolerance to heat, chilling stress and drought in bean plants. It also regulates the jasmonate dependent channel in many plants. The foliar application of $\mathrm{K}_{2} \mathrm{HPO}_{4}$ at the rate of $25 \mathrm{mM}$ decreased the infection of powdery mildew on barley by $70 \%$, with a substantial increase in the grain production was about $12 \%$ compared with the control (Mitchell and Walters, 2004). Calcium chloride, potassium dibasic phosphate and salicylic acid were used to manage the E. pisi under in-vitro and in-vivo experiments. In all the experiments the plant activators gave significant results, reduced the disease severity, increased plant length and fresh foliage weight was also increased as compared to check (Ashour, 2009).

However, the control of plant diseases by chemical treatments is an easy, direct and quick method to overcome the plant disease problems. The incessant dependence on pesticides has verified to be inappropriate and contributed to more difficulties in pest control such as ecological pollution and deprivation. Control of powdery mildew by nutrients and plant activators has facilitated to avert such anomalies because it is environmentally sound and appropriate approach which tries to abate the practice of chemicals. The current studies provide a new means for the effective management of powdery mildew of pea by implementing the safe and appropriate approaches. The disease control with plant activators and nutrients, especially macronutrients and salicylic acid application provided a skylight for future biochemical framework for isolation, purification and concentration of active antifungal compounds. Choice of appropriate formulation and method of application could be the future planes of plant disease control related research.

\section{Conclusion}

Pea is a highly demanding vegetable crop in Pakistan and in the world. In the current research thirteen verities/lines were screened out against the highly devastating fungal pathogen Erysiphe pisi. Peas 2009 was observed to be the highly resistant variety against the powdery mildew. Among the nutrients and plant activators the macronutrients and salicylic acid were most effective in minimizing the disease incidence as $8.14 \%$ and $16.38 \%$ respectively.

\section{Disclaimer: None. \\ Conflict of Interest: None. Source of Funding: None.}

\section{References}

Ali Z, Qureshi AS, Ali W, Gulzar H, Nisar M and Ghafoor A, 2007. Evaluation of genetic diversity present in pea (Pisum sativum L.) germplasm based on morphological traits, resistance to powdery mildew and molecular characteristics. Pak. J. Bot. 39: 2739-2747.

Ashour A, 2009. Effect of application of some systemic fungicides and resistance-inducing chemicals on management of cantaloupe powdery mildew disease. Egypt J. Phytopathol. 37: 1-8.

Azmat MA, Nawab NN, Niaz S, Rashid A, Mahmood K, Khan AA and Khan SH, 2010. Single recessive gene controls powdery mildew resistance in pea. Int. J. Veg. Sci. 16: 278-286. 
Cao A, Xing L, Wang X, Yang X, Wang W, Sun Y, Qian C, Ni J, Chen Y and Liu D, 2011. Serine/threonine kinase gene Stpk-V, a key member of powdery mildew resistance gene Pm21, confers powdery mildew resistance in wheat. Proceed. Nat. Acad. Sci. 108: 7727-7732.

Conrath U, 2006. Systemic acquired resistance. Plant Signal Behav. 1: 179-184.

Dong H and Beer S, 2000. Riboflavin induces disease resistance in plants by activating a novel signal transduction pathway. Phytopathol. 90: 801-811.

Dordas C, 2009. Dry matter, nitrogen and phosphorus accumulation, partitioning and remobilization as affected by $\mathrm{N}$ and $\mathrm{P}$ fertilization and source-sink relations. Eur. J. Agron. 30: 129-139.

Edreva A, 2004. A novel strategy for plant protection: Induced resistance. J. Cell Mol. Biol. 3: 61-69.

Fageria NK, 2016. The use of nutrients in crop plants: CRC press.

Fondevilla S, Carver T, Moreno M and Rubiales D, 2006. Macroscopic and histological characterisation of genes er1 and er2 for powdery mildew resistance in pea. Eur. J. Plant Pathol. 115: 309-321.

Fondevilla S and Rubiales D, 2012. Powdery mildew control in pea. A review. Agron. Sustain. Dev. 32: 401-409.

Horsfall JG, 2012. Plant Disease: An Advanced Treatise: How Plants Suffer from Disease: Elsevier.

Hussain SI, Mahmood T, Khokhar K, Laghari M and Bhatti M, 2002. Screening of pea germplasm for yield and resistance towards powdery mildew. Asian J. Plant Sci. 1: 230-231.

Katoch V, Sharma S, Pathania S, Banayal D, Sharma S and Rathour R, 2010. Molecular mapping of pea powdery mildew resistance gene er2 to pea linkage group III. Mol. Breeding. 25: 229-237.

Marx G, 1971. New linkage relations for chromosome III of Pisum. Pisum Newslett. 3: 18-19.

Mayee C and Datar V, 1986. Phytopathometry, Technical Buletien-1 (Special Bulltetin-3), Marathwada Agric. Univ. Parbhani, India. 218.

Mitchell AF and Walters DR, 2004. Potassium phosphate induces systemic protection in barley to powdery mildew infection. Pest Manage. Sci.: formerly Pesticide Sci. 60: 126-134.

Muneer F, Johansson E, Hedenqvist V, Plivelic TS, Markedal KE, Petersen IL, Sorensen JC and
Kuktaite R, 2018. The impact of newly produced protein and dietary fiber rich fractions of yellow pea (Pisum sativum L.) on the structure and mechanical properties of pasta-like sheets. Food Res. Int. 106: 607-618.

Naeem S, Ahmad S, Ul Hassan M, Adil M, Younis MA, Azeem M and Ibrahim M, 2018. Role of pollinators in pea (Pisum sativum) yield at Peshawar valley. J Entomol. Zool. Stud. 6: 1280-1282.

Nisar M, Ghafoor A, Khan MR and Qureshi AS, 2006. Screening of Pisum sativum L. germplasm against Erysiphe pisi Syd. Acta Biol. Crac. Ser. Bot. 48: 3337.

Shahid M, Shah S, Ghufranulhaq, Ali H and Ishtiaq S, 2010. Resistance in pea germplasm/lines to powdery mildew under natural conditions. Mycopath. 8: 7780.

Sreeja S, 2014. Synthetic plant activators for crop disease management. Lifesci. Leaflets. 48: 92-106.

Steel D, Robert G and Torrie JH, 1986. Principles and procedures of statistics: a biometrical approach: McGraw-Hill.

Sun S, Deng D, Wang Z, Duan C, Wu X, Wang X, Zong $X$ and Zhu Z, 2016. A novel er1 allele and the development and validation of its functional marker for breeding pea (Pisum sativum L.) resistance to powdery mildew. Theor. Appl. Genet. 129: 909919.

Vallad GE and Goodman RM, 2004. Systemic acquired resistance and induced systemic resistance in conventional agriculture. Crop Sci. 44: 1920-1934.

Veneklaas EJ, Lambers H, Bragg J, Finnegan PM, Lovelock CE, Plaxton WC, Price CA, Scheible WR, Shane MW and White PJ, 2012. Opportunities for improving phosphorus-use efficiency in crop plants. New Phytol. 195: 306-320.

\section{Contribution of Authors}

Ikram A: Performed the experiment

Aslam HMU: Manuscript write up and editing

Atiq M: Statistical analysis

Amrao L: Designed the study

Ali S: Designed the study and manuscript write up

Khan NA: Helped in experimental work

Naveed K: Helped in experimental work 